\title{
Penerapan Metode Buzz Group untuk Meningkatkan Hasil Belajar Biologi Pada Siswa Kelas IX SMPN 1 Besuki
}

\author{
Suparmi ${ }^{1}$ \\ ${ }^{1}$ SMPN 1 Besuki, Tulungagung \\ Email: ${ }^{1}$ suparmi.ta@gmail.com
}

\begin{tabular}{l} 
Tersedia Online di \\
\hline http://www.jurnal.unublitar.ac.id/ \\
index.php/briliant \\
\hline \\
\hline Sejarah Artikel \\
\hline Diterima pada 29 Januari 2018 \\
Disetuji pada 30 Januari 2018 \\
Dipublikasikan pada 13 Februari \\
2018 Hal. 25-36
\end{tabular}

Kata Kunci:

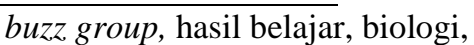

\section{DOI:}

http://dx.doi.org/10.28926/briliant .v3i1.132

\begin{abstract}
Abstrak: Berdasarkan hasi observasi yang dilakukan di Kelas IX A pada waktu pembelajaran Biologi diperoleh hasil bahwa Hasil belajar siswa memuaskan, yaitu siswa lainnya masih belum dapat mencapai KKM atau $\geq 700$, sedangkan 27 siswa lainnya masih belum dapat mencapai $\mathrm{KKM}$ atau 69, Untuk itu, dilakukan penelitian ini dengan menerapkan metode buzz group guna menyelesaikan masalah tersebut. penelitian ini merupakan suatu penelitian tindakan kelas dengan subyek siswa kelas IX A SMPN 1 Besuki. Hasil penelitian menunjukkan adanya peningkatan Hasil belajar siswa berdasarkan nilai post test per siklus dengan nilai di atas KKM yaitu persentase pada siklus I 52,9\% dan pada siklus II $88,2 \%$
\end{abstract}

Mata pelakaran biologi dikembangkan melalui kemampuan berpikir analitiis, indukif dan deduktif untuk menyelesaikan masalah yang berkaitan dengan peristiwa alam sekitar dan penyelesaian bersifat kualitatif dan kuantitatif dilakukan. Dengn menggunakan pemahaman dalam bidang lainnya. Mata pelajaran biologi di SMP merupakan keanjutan IPA di SMP yang menekankan pada fenomena alam.

Proses pembelajaran bioogi merupakan penciptaan situasai dan kondisi yang konduktif sehingga terjadi interaksi antara subjek didik dengan objek belajarnya yang berupa makhluk hidup dan segala aspek kehidupannya. Melalui interaksi antara subjek didik dengan objek belajar dapat menyebabkan perkembangan proses menta dan sensori motorik yang optimal pada diri siswa. Akan tetapi, guru dalam proses pembelajaran juga dapat mempengaruhi peningkatan hasil belajar Biologi siswa, salah satuya dengan pengggunaan metode pembelaajran yang tepat oleh Guru sesuai dengan materi yang disampikan. Mata penalajaran biologi berfungsi untk menamkan kesadaran terhadap keindahan dan keteraturan alam sehingga peserta didik dapat mempengaruhi peningkatan hasil belajar Biologi siswa, salah sutunya dengan menggunakan metode pembelajaran yag tepat oleh Guru sesuai dengan materi yang disampaikan. Mata pelajaran BIologi berfungsi untuk menanamkan kesadaran terhaap keindahan dan 
keteraturan alam sehingga peserta didik dapat meningkatkan keyakinannya terhadap keagungan pencipta, sehinngga warga Negara yang menguasai ilmu sains dan teknologi untuk meningkatkan mutu kehidupan dan melanjutkan pendidikan ke jenjang yang lebih tinggi. (Sudjoko, 2001).

Kreativitas seorang Guru dalam pembelajaran, dapat dilihat dari sejauh maa Guru dapat menentukan model pembelajaran yang sesuai dengan erkembangan mental dan keterlibatan emosional siswa. Guru yang kreatif, akan mampu memilih metode yang cocok dengan karakteristik siswa dan karakteristik mata pelajaran Biologi yang di ajarkan. Penetuan metode yang dilakukan Guru, turut menentukan efektifitas dan efisiensi proses belajar menggajar. Proses pembelajaran yang dilakukan dengan metode yang sesuai dengan demontrasi sehingga siswa tidak merasa terbebani oleh materi pembelajaran tersebut.

Apalagi mata pelajaran Biologi menuntut kemampuan Guru untuk bisa membuat siswa mengerti dan memahami tentang materi yang diajarkan dengan tidaj hanya membaca buku dan teori saja melainkan harus disertai alat peraga, contoh, praktek, latihan soal, seperti ilmiah yang berujuang pada pemerolehan Hasil belajar yang maksimal.

Berdasarkan hasil pengamatan dalam proses belajar mengajar dikelas, keadaan sekolah, dan melalui peninjauan bidang akademik dan non akademik, dieproleh hasil bahwa keadaan Sekolah Menengah Pertama Negeri 1 Besuki Tulungagung khususnya siswa kelas IX A tahun ajaran 2014/2015 dalam pelajaran Biologi belum menunjukkan Hasil belajar sesuai dengan KKM yang ditetapkan teruama pada materi pelajaran pewarisan sifat pada makhluk hidup. Padahal, ditinjau dari keadaan fisik sekolah, yaitu ruang kelas IX A sudah baik dan sesuai sebagai tempat berlangsungnya proses belajar mengajar. Pengamatan pada proses pembeajaran oleh peneliti dapat disimpulkan bahwa pelaksanaan proses belajar mengajar lah yang belum membuat siswa aktif belajar, sehingga kemampuan siswa belum tergali dengan maksimal.

Pada ulangan harian Biologi dengan materi pewarisan sifat pada makhluk hidup, di dapat rata-rata nilai sebesar 61,9 dari 44 siswa, padahal Kriteria Ketuntasan Minimalnya (KKM) telah ditentukan nilai sebesar 70. Dan hanya 17 siswa yang mendapat nilai diatas 70 . Hal ini berarti hanya $38,6 \%$ dari siswa yang telah mencapai ketuntasan belajar, dan yang lainnya memiliki hasil belajar yang rendah. Hasil belajar merupakan bagian terpentingan dalam pembelajaran. Nana Sudjana (2009:3) mendefinisikan hasil belajar siswa pada hakikatnya adalah perubahan tingkah laku sebagai hasil belajar dalam pengertian yang sudah mencakup bidang kognitif, afektif, dan psikomotorik. Dimyati dan Mudjiono (2006:3-4) juga menyebutkan hasil bellajar merupakan hasil dari suatu interaksi tidak belajar. Dari sisi siswa, hasil belajar merupakan berakhirnya pengajaran dari puncak proses belajar.

Berdasarkan hal tersebut, peneliti meminta bantuan kepada teman sejawat untuk meneliti kekurangan dari pembelajaran yang telah dilaksanakan. Dari hasil diskusi dengan teman sejawat ditemukan masalah-masalah dalam proses pembelajaran Biologi yang menyebabkan menurunkan hasil belajar adalah sebagai berikut: (1) Materi kurang dapat diikuasi siswa secara optimal. (2) Siswa belum dapat menyelesaiakan soal-soal pewarisan sifat pada makhluk hidup, diantaranya tahapan manusia. Siswa mengalami kesulitan ketika harus memecahkan dan menyelesaiakan permasalahan pada bahasan ini. (3) 
Kebanyakan siswa cenderung hanya memakai ingatan hafalan untuk menentukan materi yang dipergunakan. Karena Guru memang menekankan dan mengajurkan kepada siswa untuk mencatat dan menghafal materi tersebut. Karena dilakukan secara instan, tanpa ditentukan dan ditentukan sendiri pewarisan sifat pada makhluk hidu tersebut oleh siswa, maka dihindarkan. (4) Melihat hasil ulangan harisan siswa diatas, bisa dilihat jika penggunaan metode ppembeajaran dalam pembelajaran Bioogi pada siswa kelas IX A belum sesuai dan membuat siswa terlihat tidak antusias dalam belajar. (5) Pembelajaran dengan metode konvensional yaitu dengan menjelaskan materi dan siswa hanya melakukan pemerintah menghafal materi dan mengerjakan soal tanpa penanaman konsep pembelajaran yang kuat ternyata tidak efektif dalam proses peningkatan hasil belajar siswa.

Setelah melihat hasil analisa di atas dan tukar pendapat dengan teman sejawat, maka untuk memperileh hasil belajar yang optimal, tidak hanya memerlukan suatu hafalan yang terus menerus, tetapi terlebih dahulu siswa harus mengetahui inti dari materi yang dipelajarinya. Berdasarkan konsep yang mereka temukan sendiri di dalam proses pembelajaran, tentu siswa akan lebih bersemangat, dan aktif belajar serta berusaha mencari penyelesaian masalah yang diberikan oleh Gurunya dengan menggunakan kemampuannya sendiri. Adakalanya semangat atau motivasi siswa dalam bbellajar dan konsep yang tertanam dengan baik, diharapkan siswa ampu menyelesaikan setiap tugas yang diberikan dengan prosedur yang benar, sehingga Hasil belajar yang diperoleh menjadi lebih baik dari semula.

Oleh karena itu, demi memperbaiki berbagai masalah yang ada, peneliti memerlukan siuatu solusi untuk mengatasi hambatan-hambatan yang terjadi. Akhirnya diputuskan dengan menggunakan metode buzz group. Buzz group adalah suatu kelompok dibagi kedalam beberapa kelompok kecil (sub group) yang masing-masing terdiri dari 3-6 orang dalam tempo yang diangkat, untuk mendiskusikan suatu topic atau memecahkan suat masalah seorang juru bicara ditunjuk untuk menyampaikan hasil diskusi kelompok masing-masing kepada sidang lengap seluruh kelompok. (Sujadi, 1984:34).

Metode buzz group merupakan metode yang mempersiapkan peserta didik pada situasi untuk melakukan perbandingan persepsinya yang mungkin berbeda-beda tentang ahan pelajaran membandingkan interprestasi dan informasi yang diperoleh masing-masing. Dengan demikian masing-masing individu dapat saling memperbaiki pengertian, persepsi informasi, interprestasi, sehingga dapat dihindarkan kekeliruan-kekeliruan. Sehingga hasil beajar Biologi pewarisan sifat pada makhluk hidup pun dapat meningkat. Metode mempunyai andil yang cukup besar dalam kegiatan belajar mengajar. Kemampuan yang diharapkan dapat dimiliki anak didik akan ditentukan oleh relevansi penggunaan suatu metode yang sesuai dengan tujuan. Itu berabti tujuan pembelajaran akan dapat dicapai dengan penggunaan metode yang tepat, sesuai dengan standar keberhasilan yang terpatri di dalam suatu tujuan.

Menindaklanjuti permasalahan dan solusi yang ditawarkan maka peneliti tertarik utnuk melakukan suatu penelitian guna ningkatkan hasil belajar biologi siswa kelas IX A di SMP Negeri 1 Besuki lungagung melalui penerapan metode buzz group. Sehingga tujuan dari penelitian ini adalah mengetahui (1) bagimanakah penerapan metode buzz group buntuk meningkatkan hasil belajar 
biologi siswa kelas IX A SMPN 1 Besuki dan (2) apakah metode buzz group dapat meningkatkan hasil belajar biologi siswa kelas IX A siswa kelas IX A SMPN 1 Besuki.

\section{METODE}

Subjek yang digunakan seluruh siswa kelas IX A Sekolah Menengah Pertama Negeri 1 Besuki Tulungagung tahun pelajaran 2014/2015 sebanyak 44 siswa yang terdiri dari 24 siswa putra dan 22 siswa putrid. Lokasi yang digunakan tempat penelitian adalah ruang kelas IX Sekolah Menengah Pertama Negeri 1 Besuki Tulungagung tahun pelajaran 2014/2015.

Metode yang digunakan adalah metode penelitian Tindakan Kelas yang dikembangkan oleh Kemmis dan Mc Taggart (1988) yakni perencanaan (planning), tidakan (acting), observasi (observing) dan refleksi (feflecting). Penelitian ini dilakukan dalam 2 siklus, yang dimulai dari refleksi pada sebelum pelaksanaan perbaikan pembelajaran dimulai. Namun jika setelah siklus ke-II masih belum menunjukkan adanya peningkatan hasil belajar dan pemahaman siswa, maka akandilakukan sampai siklus ke-III. Penelitian ini dilakukan dengan dua siklus, dimana masing-masing diklus dikenai perlakuan yang sejenis dengan bobot yang beda. Dibuat dua siklus dimaksudkan untuk memperbarui system pengajaran yang dilaksanakan.

Adapaun ragam intrusment penelitian kelas yang telah dipersiapkan yaitu, rencana Pelaksaaan Pembelajaran sebagai intrusment rencana pelaksanaan tindakan. Lembar observasi Guru sebagai intrusment utama pengumpul data proses dan lembar observasi siswa, wawancara, angket dan catatan lapangan sebagai intrusment pendukung pengumpul data proses. Selain itu juga terdapat intrusmen pengumpul data hasil, yang dapat dikumpukan dari hasil belajar berdasarkan soal-soal yang diberikan, serta keterampilan siswa berdasarkan rublik yang ada.

Analisis data dari sumber-sumber informasi hasil penelitian di dapat dari: (1) Analisis Data Observasi, Data hasil observasi keterlaksanaan pembelajaran melalui Metode mind mapping dan observasi aktivitas siswa dianalisis secara deskriptif untuk memberikan gambaran pelaksanaan pembelajaran dengan menggunakan Metode buzz group. (2) Analisis Data Wawancara, Hasil wawancara dengan siswa dianalisi secara deskriptif dengan lembar angket untuk mengetahui pendapat Guru dan siswa terhadap pembelajaran. (3) analisis Data Tes, Berdasarkan hasil tes siswa setiap soal diberi skor kemudian diperoleh nilai utuk setiap siswa.

\section{HASIL}

\section{Pra Siklus}

Berdasarkan kondisi awal di atas, maka akan ditetapkan metode buzz group, sehingga siswa kelas IX A SMP Negeri 1 Besuki Tulungagung tahun ppelajaran 2014/2015 dapat mengatasi kesulitan belajar dan menguasai materi tentang pewarisan sifat pada makhluk hidup. Table berikut adalah daftar frekuensi nilai ulangan harian Biologi materi pewarisan sifat pada makhluk hidup siswa kelas IX A SMP Negerii 1 Besuki Tulungagung, dengan nilai KKM terbesar 70: 
Tabel 1 Daftar Nilai Ulangan Harian Kondisi Awal

\begin{tabular}{|c|c|c|}
\hline Nilai & Frekuensi & Prosentase \\
\hline $0-40$ & 4 & $9,1 \%$ \\
\hline $41-69$ & 23 & $52,3 \%$ \\
\hline $70-100$ & 17 & $38,6 \%$ \\
\hline Jumlah & 44 & $100 \%$ \\
\hline
\end{tabular}

Dari tabel diatas dapat kita lihat ada 4 siswa atau 9,1\% yang mendapat nilai antara $0-40$, ada 23 siswa atau 52,3\% yang mendapat nilai antara 41-69, aa 17 siswa atau 38,6\% yang mendapat nilai anatara 70-100. Dengan ketentuan nilai KKM 70, maka dapat disimpulka jika pencapaian presentasi nilai 70-100 yag hanya 38,6\% merupakan presentasi yang rendah. Selain itu, dari proses wawancara diperoleh kesimpulan bahwa siswa kurang berminat dalam belajar Biologi apalagi harus menghafal materi, karena Guru lebih sering menggunakan ceramah sehingga siswa merasa jenuh dan bosan, akibatnya minat siswa untuk belajar Biologi terutama pada materi pewarisan sifat pada makhluk hidup menjadi berkurang sehingga mempengaruhi hasil belajarnya.

Berdasarkan hasil data yang dikumpulkan, apat dikemukakan dua hal pokok yang perlu diatasi, yaitu menumbuhan minat siswa untuk Belajar Biologi dan memahamkan materi pewarisan sifat pada mkhluk hidup dengan menatifkan siswa dalam kegiatan belajar mengajar dan meningkatkan hasil belajar siswa dengan menerapkan metode buzz group pada siklus 1 nanti dengan harapan hasil belajar siswa dapat meningkat. Jika pada siklus 1 , targen indicator pencappaian hasil belajar masih kurang dari 85\% maka akan ilakukan dengan siklus 2 dan seterusnya, sehingga target indicator pencapaian peningkatan hasil belajar siswapada pelajaran Biologi materi Pewarisan sifat pada mkhluk hisup dapat terpenuhi, yaitu $85 \%$ atau lebih.

\section{Siklus I}

\section{Observasi Siswa}

Kegiatan observasi dilaksankan saat proses pembelajaran Biologi berlangsung. Kegiatan observasi difokuskan pada pelaksanaan pembelajaran. Dalam kegiatan ini, Guru mengamati jalannya pembelajaran. Pertama-tama Guru mengamat kelengkapan peralatan siswa, untk dapat digunakan dalam kegiatan pembelajaran. Kedua Guru mengamati langkah-langkah kegiatan siswa ketika melaksanakan kegiatan pembelajaran, sudah sesuaikkah langkah yang ditempuh siswa dengan langkah-langkah yang tertera dalam lembar kegiatan. Hasilnya, masih ada kelompok yang terlihat bingung dalam pelaksanaannya, ada yang kurang teliti, ada pula yang bingung dengan langkah yang harus dilakukan. Ketiga, Guru mengamati keaktifan siswa saat melaksanakan kegiaan ada beberpa siswa yang tidak aktif dalam melaksanakan kegatan, siswa tersebut hanya berdiam diri seolah-olah tidak mau tahu.

Pengamatan selanjutnya guru mengamati bagaimana keaktifan siswa ketia berdiskusi untuk menarik simpulan, ada beberapa siswa yang aktif bergumen dan ada yang berdiam diri saja. Pengamatan yang paling alhir adalah bagaimana kesimpulan hasil diskusi siswa, adapakah sesuai dengan hasil pelaksanaan percobaan atau tidak. Dari pengmatan yang terakhir ini ada 2 (dua) kelompok yang belum berani mepresentasikan hasil temuan, dan hanya terdapat 4 (empat) 
siswa yang mau mengajukan persyaratan. Hal ini disebabkan, kurangnya petunjuk dan bimbingan dari Guru.

Dari urian di atas dapat disimpulkan hasil observasi dari siklus I antara lain: sebaian besar siswa melakukan penelitia secra berkelompok dengan antsia. Sebagian besar siswa terlihat aktif dalam pembelajaran dengan menggunakan metode buzz group. Sebagian besar siswa sudah memperhatikan penjelasan guru. Hanya ada 4 siswa yang memperhatikan, mereka justru mengajak bicara dengan teman sebangkunya. Sebagian besar siswa sudah dapat mengelompokkan dengan baik, hanya terdapat 2 kelompok yang sering berselisish dengan anggota kelompoknya. Baru terdapat sebagian kecil siswa yang ikut ambil bagian dala diskusi kelompok. Sebagan besar sisw justru saling berbincang dengan teman duduknya. Terdapat 5 (lima) kelompok yang melaksanakan diskusi dengan sungguh-sungguh. Dari 9 (Sembilan) kelompok, baru terdapat 5 (lima) kelompok yang sudah berani mempresentasikan hasil temuan kelompoknya, sedangkan 4 (empat) kelompok yang belum berani.

Kegiatan penelitian pewarisan sifat pada makhluk hidup dalam 2 jam pelajaran di rasa kurang terlaksana dengan baik, karena dalam waktu tersebut, beberapa anggota kelompo belum memhami cara penggunaan cakram genetika, sehingga dibutuhkan penguatan kegiatan penelitian lagi pada siklusnya. Sewaktu presentasii hasil kelompoj dilakukan, hanya terdapat 4 (empat) siswa yang mau mengajukan pertanyaan. Sehingga dapat disimpulkan jika siswa kurang maksimal dalam menyerap konsep yang diajarkan. Masih ada beberapa siswa yang belum aktif dalam menjawab pertanyaan.

\section{Hasil Obsrvasi Kegiatan Guru}

Melakukan pembelajaran sesuai dengan rencn pembelajaran yang telah disusun. Guru membuka pelajaran dengan baik, mengbsen siswa dan menyampaiakan tujuan pembelajaran. Melaksanakan demonstrasi yang sesuai dengan materi. Menjelaskan tentang pembelajaran dengan metode buzz group. Karena masih baru di perkenalkan oleh siswa, beberapa sisw masih tampak bingung. Mengamati jalannya proses pembelaaran dan meilai kemampuan siswa dalam menyelesaikan tugas ddalam kelompoknnya. Aktif membimbing siswa. Selama diskusi berlangsung guru berkeliling mengawasi, membimbing $\mathrm{dn}$ menjelaskan kepada siswa atau kelompok yang juga memotivsi siswa agar melakukan diskusi dengan baik. Guru menyuruh salah satu siswa untuk mempresentasikan hasil temuan kelompoknya dan memeriksa serta mengevaluasi degan baik penelitian pewarisan sifat pada mahkluk hidup daam 2 jam pelajaran, di rasa kurang optimal.

Dalam pelaksanaan pembelajaran, Guru masih menghadpi berbagai kendala, antara lain: beberapa anggota kelompok belum memahami cara penggunaan cakram genetika. Masih ada kelompok yang bingung dalam mengikuti langkah-langkh yang tertera dalam lembar kegitan. Masih adda beberapa siswa yang belum aktif dalam pelksanaan percobaan. Masih terdapat beberapa siswa yang hanya bermain-main saat kegiatan berlangsung. Ketika pelaksanaan diskusi, ada beberapa siswa yang tidak aktif menyampaikan pendaaptnya. Dalam menyimpulkan hasil percobaan terdapat 2 (dua) kelompok yang malu untuk presentasi, dan hanya terdapat 4 (empat) siswa yang mengajukan pertanyaan. 
Adapun prosentase hasil observasi dalam pelaksanaan percobaan pada siklus I dapat diihat dari table 3 bawah ini. perhitungan prosentase keberhasilan siklus I di bawah ini diskusian juga dengan teman sejawat.

Tabel 1 Prosentase Hasil Observasi Siklus I

\begin{tabular}{|c|l|c|}
\hline No & Kegiatan Siswa & Prosentase \\
\hline 1 & Kelengkapan menyiapkan alat dan bahan percobaan & $40 \%$ \\
\hline 2 & Keruntutan langkah-langkah dalam pelaksanaan kegiatan percobaan & $45 \%$ \\
\hline 3 & Keaktifan siswa selama melakukan kegiatan percobaan & $65 \%$ \\
\hline 4 & Keaktifan siswa dalam mengutarakan pendapat saat berdiskusi & $50 \%$ \\
\hline 5 & Kesimpulan akhi sesuai percobaan & $50 \%$ \\
\hline
\end{tabular}

Hasil post test pada siklus pertama dapat menjadi perhitungan prosentase peningkatan hasil beajar siswa. Dengan acuan peilaian tetap berdasarkan nilai KKM yang telah ditetapkan yait paling sedikit siswa memperoleh 70. Adapun rekapitulasi hasil test siklus I adalah sebagai berikut:

Tabel 2 Hasil Post Test Siklus Pertama

\begin{tabular}{|c|l|c|}
\hline No & Deskripsi & Nilai \\
\hline 1 & Jumlah Nilai & 3180 \\
\hline 2 & Rata-rata Hasil Post Test & 72,3 \\
\hline 3 & Jumlah siswa yang mendapat nilai diatas KKM (70) & 27 \\
\hline 4 & Presentase siswa yang mendapat nilai diatas KKM (70) & $61,4 \%$ \\
\hline 5 & Jumlah siswa yang mendapat nilai dibawah KKM (70) & 17 \\
\hline 6 & Presentase siswa yang mendapat nilai dibawah KKM (70) & $38,6 \%$ \\
\hline
\end{tabular}

Nilai rata-rata hasil post test, dapat dihitung dari :

$X \frac{\sum x}{\sum N}$, jadi $X \frac{3180}{44}=72,3$

Nilai $\mathrm{KKM}=70$, jadi sudah ada peningkatan hasil belajar, namun hanya sedikit, Materi Ketuntasan Individu (hasil belajar Siswa) =

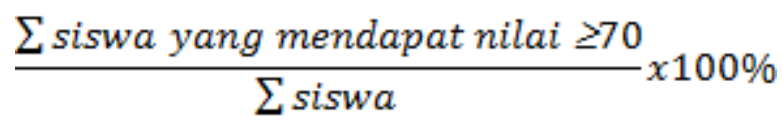

Jadi, Ketuntasan Individu (asil belajar siswa) $=\frac{27}{44} \times 100 \%=61,4 \%$. Masi kurang dari indicator pencapaian siklus I sebesar $85 \%$ atau lebih. Maka dilanjutkan percobaan pembelajaran dengan metode buzz group pada siklus II.

Tabel berikut adalah daftar frekuensi nilai post test siklus I Biologi materi pewarisan sifat padda makhluk hidup siswa kelas IX A SMP Negeri 1 Besuki Tulungagung tahun pelajaran 2014/2015 setelah pembelajara menggunakan metode buzz group, dengan nilai minimal KKM sebesar 70: 
Tabel 3 Daftar Nilai Ulangan Harian Siklus I

\begin{tabular}{|l|l|l|}
\hline Nilai & Frekuansi & Prosentase \\
\hline $0-40$ & 0 & $0,0 \%$ \\
\hline $41-69$ & 17 & $38,6 \%$ \\
\hline $70-100$ & 27 & $61,4 \%$ \\
\hline Jumlah & 44 & $100 \%$ \\
\hline
\end{tabular}

Dari tabel diatas dapat kita lihat terdapat 17 siswa atau 38,6\% yang mendapat nilai antara 41- 69, dan 27 siswa atau 61,4\% yang mendapat nilai $70-$ 100. Dengan ketentuan nilai KKM 70 dapat disimpulkan jika pencapaian presentasi nilai 70-100, maka hasil belajar siswa telah meningkat dari 38,6\% menjadi $61,4 \%$. Namun karena belum mencapai target indicator pencapaian siklus sebesar $85 \%$ atau lebih, maka akan dilanjutkan ke Siklus II. Selain itu, dari proses wawancara diperoleh kesimpulan bahwa beberapa siswa menjadi bersemangat dalam bidang belajar Biologi, karena pelaksanaan kkegiatan belaar Bioogi yang menggunakan metode buzz group ini dilaksanakan dengan langsung melibatan siswa secara aktif dan mandiri, dan melaksanakan kegiatan bersama kelompok sehingga ebih ringan. Meskipun mmasih terdapat kendala-kenadala seperti yang telah diuraikan dalam laporan observasi.

\section{SIKLUS II}

\section{Hasil Observasi Kegiatan Siswa}

Sama degan pelaksanaan observasi pada siklus I, kegiata observasi siklus kedua dilaksanakan saat proses pembelajaran Biologi berlangsung. Kegiatan observasi difokuskan pada pelaksanaan pembelajaran. Dalam kegiatan ini, guru mengamati jalannya pembelajaran. Namun dalam kegiatan observasi Siklus I, Guru juga mengamati kelengkapan bahan ajar yang dibawa oleh siswa dari rumah, yaitu kantong plastik hitam 2 buah, kancing merah 100 buah dan kancing putih 100 buah.

Karena kelompok masih sama dengan siklus yang pertama, kegiatan pembelajaran menjadi lebih efektif, karena terlihat siswa telah akrab dan nyaman dengan anggota kelompoknya yang lain. Kedua, Guru mengamati langkahlangkah kegiatan siswa kettika melakukan percobaan, sudah sesuaikah langkah yang ditempuh siswa dengan langkah-langkah yang tertera dalam lembar kegiatan. Hasilnya, semua kelompok dapat memahami langkah-langkah pembelajaran dan dapat menjalankan kegiatan sesuai dengan lembar kegiatan yang tersedia. Ketiga, Guru mengamati keaktifan siswa saat melaksanakan percobaan. Pada siklus II ini kebanyakan siswa telah aktif dalam mengikuti pelaksanaan percobaan, haya terdapat 2 (dua) siswa yang terlihat mengobrol ataupun berdiam diri.

Pengamatan selanjutnya, Guru mengamati bagaimana keaktifan siswa ketika berdiskusi untuk menarik simpulan, karena mereka membuat penelitian secara mandiri, mereka lebih antusias dalam mengambil kesimulan. Ppengamatan yang paling akhir adalah bagimana kesimpulan hasil diskusi siswa, apakah sesuai dengan hasil pelaksanaan percobaan atau tidak. Ari pengamatan yang terakhir ini, dengan adanya reward yang diberikan oleh Guru, semua kelompok melaksankan penelitian dengan aktif dan berani memppresentasikan hasi temuannya, dan hanya terdapat 2 (dua) siswa yang kurang aktif dalam diskusi. 
Dari uraian di atas dapat disimpulkan hasil observasi dari Siklus II antara lain: sebagian besar siswa melaksankan penelitian secara berkelompok dengan antusia Sebagian besar siswa terlibat aktif dalam pembelajaran dengan menggunakan metode buzz group dengan cara siklus II. Hampir semua siswa merasa nyaman dengan cara pembagian kelompok yang tidak berubah, masih sebagian besar siswa merasa nyaman dengan cara pembagian kelompok yang tidak berubah, masih saa seperti halnya siklus pertama. Dengan adanya rewed, terdapat sebagian besar siswa yang ikut ambil bagian dalam diskusi kelompok. Sebagian kecil siswa masih tampak saling berbincang dengan teman dudukya ataupun melamun. Diskusi dilakukan dengan baik. 9 (Sembilan) kelompok yang terbagi, mereka sudah dapat menyelesaikan lembar kegiatan dengan tepat waktu. Siswa yang terlihat lemah pada siklus I, lebih banyak mendapat perhatian dan bimbingan dari Guru.. dengan adanya reward, 9n(Sembilan) kelompok sudah berani mempresentasikan hasil temuan kelompoknnya. Mereka tampak detail dalam mempresentasikan hasil temuannya.

Metode pelaksanaan pembelajaran metode buzz group dengan penelitian yang media pembelajaranya dibawa sendiri kemudan hasil pengamatan didikusikan bersama-sama dengan kelompok menunjukkan hasil yang efektif dan semakin mematangkan pemahaman siswa. Sewaktu presentasi hasil kelompok dilakukan, dengan adanya reward, hampir semua siswa mengajukan pertanyaan, hanya terdapat 2 (dua) siswa yang masih malu mengajukan pertanyaan. Sehingga dapat disimpulkan bahwa penerapan metode buzz group siklus II ini maksimal dalam menyerap konsep yang diajarkan. Hasil post test menunjukkan hasil belajar siswa pun meningkat.

\section{Hasil Observasi Kegiatan Guru}

Pergantian pelaksanaan pembelajaran metode buzz group dilaksankan degan baik. Melaksankan pembelajaran sesuai dengan renccana pembelajaran yang telah disusun. Guru membuaka pelajaran dengan baik, mengabsen siswa dan menyampaikan tujuan pembelajaran. Menjelaskan kembali tentang pembelajaran dengan metode buzz group. Karena teah dikenalkan sebelumnya maka siswa telah memahami konsep dengan baik. Mengamati jalannya proses pembelajaran da menilai kemampuan siswa dalam menyelesaikan tugas dalam kelompoknya. Aktif membimbing siswa. Selama diskusi berlangsung Guru berkeliling mengawasi, membimbing dan menjelskan kepada siswa atau kelompok yang memerluan penjelasan akan temuannya, agar hasil yang dicapai lebih optimal. Selain itu, guru juga memotivasi siswa agar melakukan diskusis lebih baik lagi dan memberikan reward bagi mereka yang berani tampil presentasi. Karena siswa anggota kelompok melaksankan penelitian secara mandiri sesuai tugasnya masing-masing dan diselesaika bersama degan teman kelompok, maka penelitiian-pun terlihat lebih efektif dan maksimal.

Dalam pelaksaanan proses pembelajaran, Guru telah melaksankan perbaikan dari siklus I, siswa sudah mengalami kemajuan dan pelaksanaan siklus II, yaitu: beberapa anggota kelompok tampak kurang kompak dalam mengambil kancing dan saat mencatat hasil pengambilannya. Masih terdaat 2 (dua) siswa yang malu dalam presentasi da kurang aktif dalam diskusi kelompok. 
Adapun prosesntase hasil observasi dalam pelaksanaan percobaan pada siklus II dapat dilihat dari table di bawah ini. perhitungan prosentase keberhasilan siklus II di bawah ini diskusiskan juga dengan teman sejawat.

Tabel 4 Prosentase Hasil Observasi Siklus II

\begin{tabular}{|l|l|l|}
\hline No & Kegiatan Siswa & Prosentase \\
\hline 1 & Kelengkapan menyiapkan alat dan bahan percobaan & $74 \%$ \\
\hline 2 & Keruntutan langkah-langkah dalam pelaksanaan kegiatan percobaan & $80 \%$ \\
\hline 3 & Keaktifan siswa selama melaksanakan kegiatan percobaan & $85 \%$ \\
\hline 4 & Keaktifan siswa dalam mengutarakan pendapat saat berdiskusi & $80 \%$ \\
\hline 5 & Kesimpulan akhir sesuai percobaan & $80 \%$ \\
\hline
\end{tabular}

Hasil post test pada siklus dapat menjadi perhitungan presentase peningkatan Hasil belajar siswa. Dengan acuan penilaian tetap berdasarkan nilai KKM yang telah ditetapkan yaitu paling sedikit siswa memperoleh nilai 70 . Adapun rekapitulasi hasil test siklus II adalah sebagai berikut:

Tabel 5 Hasil Post Test Siklus Kedua

\begin{tabular}{|l|l|l|}
\hline No & Deskripsi & Nilai \\
\hline 1 & Jumlah Nilai & 3640 \\
\hline 2 & Rata-rata Hasil Post Test & 82,7 \\
\hline 3 & Jumlah siswa yang mendapat nilai diatas KKM (70) & 38 \\
\hline 4 & Presentase siswa yang mendapat nilai diatas KKM (70) & $86,4 \%$ \\
\hline 5 & Jumlah siswa yang mendapat nilai dibawah KKM (70) & 6 \\
\hline 6 & Presentase siswa yang mendapat nilai dibawah KKM (70) & $13,6 \%$ \\
\hline
\end{tabular}

Nilai rata-rata hasil post test, dapat dihitung dari :

$X \frac{\sum x}{\sum N}$, jadi $X \frac{3640}{44}=82,7$

Nilai $\mathrm{KKM}=70$, jadi sudah ada peningkatan hasil belajar, namun hanya signifikan, Materi Ketuntasan Individu (hasil belajar Siswa) =

$\sum$ siswa yang mendapat nilai $\geq 70$

\section{$\sum$ siswa}

Jadi, Ketuntasan Individu (asil belajar siswa) $=\frac{38}{44} \times 100 \%=86,4 \%$. Telah mencapai indicator pencapaian siklus II sebesar $85 \%$ atau lebih. Maka perlu dilanjutkan percobaan pembelajara dengan metode buzz group pada siklus III.

Tabel berikut adalah daftar frekuansi nilai post test siklus II Biologi materi pewarisan sifat pada mahluk hidup siswa kelas IX A SMP Negeri 1 Besuki Tulungagung tahun 2014/ 2015 setelah penjelasan menggunakan metode buzz. group siklus II dengan nilai minimal KKM sebesar 70:

Tabel 6 Daftar Nilai Ulangan Harian Siklus II

\begin{tabular}{|l|l|l|}
\hline Nilai & Frekuansi & Prosentase \\
\hline $0-40$ & 0 & $0,0 \%$ \\
\hline $41-69$ & 6 & $13,6 \%$ \\
\hline
\end{tabular}




\begin{tabular}{|l|l|l|}
\hline $70-100$ & 38 & $86,4 \%$ \\
\hline Jumlah & 44 & $100 \%$ \\
\hline
\end{tabular}

Dari tabel diatas dapat dilihat terdapat 6 siswa atau 13,6\% yang mendapat nilai antara 41-69, dan 38 siswa atau 86,4\% yang mendapat nilai antara 70-100. Dengan ketetuan nilai KKM 70, dapat disimplka jika pencapaian presentasi nilai 70-100, maka hasil belajar siswa telah meningkat dari 61,4\% menjadi $86,4 \%$ maka telah tercapai indikator pecapaian siklus II sebesar yang $85 \%$ atau lebh, maka tidak perlu dilanjutkan ke Siklus III.

\section{PEMBAHASAN}

Berdasarkan hasil pelaksanaan pada siklus I, II dapat dinyatakan bahwa terjad peningkatan kualitas pembelajaran yang tampak dan diperoleh hasil evaluasi dan keaktifan siswa. Dari data siklus I hasil observasi mmenunjukkan, prosesntase keberhasilan kelengkapan menyiapkan alat dan bahan percobaan $40 \%$, prosentase keruntutan langkah-langkah yang ditempuh dalam pelaksanaan percobaan $45 \%$, prosentase keaktifan siswa dalam melaksanakan kegiatan percobaan $65 \%$, prosentase keaktifan siswa dalam mengutarakan pendapat saat berdiskusi $50 \%$ dan prosentase hasil penarikan keseimpulan akhir sesuai percobaan $50 \%$.

Berdasarkan data siklus II hasil observasi menunjukkan, prosentase keberhaisllan metode kelengkapan menyiapkan alat dan bahan percobaan siswa yang disiapkan $74 \%$ prosentase keruntutan langkah-langkah yang ditempuh dalam pelaksanaan percobaan $80 \%$, prosentase keaktifan siswa dalam melaksanakan kegiatan percobaan $85 \%$, prosentase keaktifan siswa dala mengutarakan pendapat saat berdiskusi $80 \%$ dan prosentase hasil penarikan kesimpulan akhir sesuai percobaan $80 \%$.

Ketika pelaksankan siklus I, peneliti mengalami berbagai kendala antara lain beberapa anggota kelompok belum memahami cara penggunaan cakram genetika. Masih ada kelompok yang bingung dalam mengikuti langkah-langkah yang tertera dalam lembar kegiatan. Masih ada beberapa siswa yang belum aktif menyampaikan pendapatnya. Dalam menyimpulkan hasil percobaan, terdapat 2 (dua) kelompok yang malu untuk presentasi, dan hanya terapat 4 (empat) siswa yang mengajukan pertanyaan.

Peneliti kemudian melaksanakan siklus II sebagai perbaikan siklus I, sebelum pelaksanaan siklus II ini penelit melengkapi renaca pembelajaran metode buzz group baru, yaitu dengan memberikan tugas kepada masing-masing anggota kelompok untuk membawa kantong plastic hitam 2 buah, kancing merah 100 buah dan kancing putih 100 buah sebagai bahan penelitan menyelidiki pperbandingan genetipe dan gentipe pada keturunan kedua dengan satu sifat beda.

Dalam pelaksanaan percobaan, peneliti senatiasa membberi bimbingan untuk siswa dalam melaksankan langkah-langkah sesuai lembar kegiatan. Peneliti pun member bimbingan siswa saat berdiskusi untk menarik kesimpulan. Dengan adanya motivasi guru berupa reward, siswa telah terlihat kreatif dalam peneitian serta aktif dalam kegiatan pembelajaran dalam melaksankan kegiatan penelitian, presentasi di depan kkeas dan berdiskusi manrik kesimullan. Meskipun ada kendala yaitu beberapa anggota kelompok tampak kurang kompak dalam mengambil kancing dan saat mencatat hasil pengabilannya, namun dengan hasil- 
hasil belajar yang dicapai dapat disimpulkan bahwa penelitian tindakan kelas dari sikuls II ini telah berhasil.

\section{KESIMPULAN}

Berdasarkan hasil penelitian kelas dan telah dilaksankan dalam 2 siklus dengan menerapkan metode buzz group dalam pembelajaran Biologi pada siswa kelas IX A SMP Negeri 1 Besuki Tulungagung tahun 2014/2015 ini, dapat dibuat kesimpulan sebagai berikut: Penerapan metode buzz group dapat meningkatkan Hasil belajar Biologi siswa kelas IX A SMP Negeri 1 Besuki Tulungagung.

\section{SARAN}

Berdasarkan hasil penelitian maka ada beberapa yang dapat diperguakan sebagai bahan pertiimbangan dan sebagai bahan uraian penutup penelitian tindakan kelas ini adalah Guru hendaknya memahami dan memvariasikan mmetode yang sesuai materi yang dapat digunakan dalam proses pengadaan berbagai media pembelajaran Biologi untuk kelas rendah, baik bantuan maupun swadaya sekolah, sehingga lebih menunjang dalam penanaman konsep-konsep biologi secara lebih nyata sekaligus meningkatkan aktivitas belajar siswa.

\section{DAFTAR RUJUKAN}

Dimyati \& Mudjiono. 2006. Belajar dan Pembelajaran. Jakarta: Rineka Cipta.

Kemmis, S. dan Mc. Taggart. 1988. The Action Research Planner. Victoria: Deakin University.

Sudjana, Nana. 2009. Penilaian Hasil Proses Belajar Mengajar. Bandung: Remaja Rosdakarya.

Sudjoko, 2001. Membantu Siswa Belajar IPA. Yogyakarta: FMIPA.UNY.

Sujadi. 1989. Membuat Siswa aktif. Bandung: Bandar Maju. 